\title{
NEW ELECTRODES FOR REPAIR SURFACING OF DAMAGED LINING OF IMPELLER CHAMBER OF HES HYDROPOWER UNITS
}

\author{
K.A. YUSHCHENKO, Yu.N. KAKHOVSKY, A.V. BULAT, V.I. SAMOJLENKO and N.Yu. KAKHOVSKY \\ E.O. Paton Electric Welding Institute, NASU \\ 11 Bozhenko Str., 03680, Kiev, Ukraine. E-mail: office@paton.kiev.ua

\begin{abstract}
New electrodes of ANV-70BG grade were developed. Relationship of structural and chemical inhomogeneity in transition zone between low-carbon steel and highly-alloyed deposited metal depending on type of the latter and value of welding current was investigated. 4 Ref., 4 Tables, 3 Figures.
\end{abstract}

$\boldsymbol{K} \boldsymbol{e} \boldsymbol{y} \boldsymbol{w} \boldsymbol{o r d} \boldsymbol{s}:$ coated-electrode manual arc surfacing, low-carbon steel, highly-alloyed deposited metal, transition zone, structural and chemical inhomogeneity, cracks, corrosion

Welded joints from dissimilar steels are widely used in chemical and power machine building. Their serviceability to significant extent is determined by condition of metal of transition zone (its structure and chemical inhomogeneity), which undergoes degradation in zone of fusion with base metal at structure operation as a result of effect of increased temperature and pressure, cyclic mechanical loadings, thermal cycling and aggressive media.

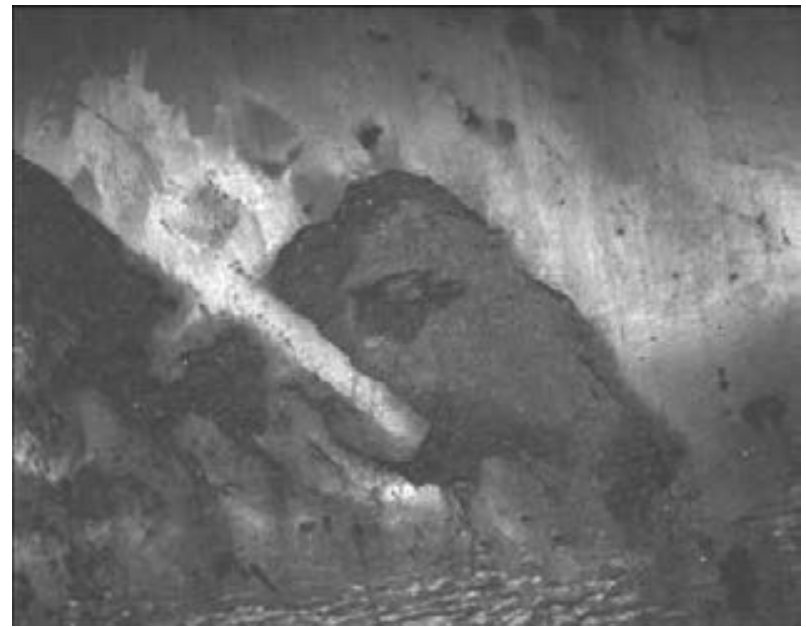

Figure 1. View of damaged metal of impeller chamber lining from St3sp steel
Different methods of arc welding are used by acting enterprises of petrochemical industry and power engineering for repair performance. Thus, repair of damaged lining from stainless steel of impeller chamber (IC) from St3sp steel is carried out in hydropower engineering for providing unit capacity. Reconstruction of its design sizes and further surfacing of highly-alloyed cavitation and corrosion resistance layer of metal on operating surface are used. Lining surfacing is often carried out by TsL-11 electrodes of E-08Kh20N9G2B type.

Examinations of fragments of metal of IC lining in one of hydropower units showed that fracture of corrosion-resistant layer deposited by TsL-11 electrodes takes place through formation of cracks, delaminations as well as corrosion in it (Figure 1). Table 1 gives chemical composition of the base and deposited metal.

The main dependencies determining inhomogeneity of chemical composition and structure in fusion zone of dissimilar metals are related with appearance of zones having conventional designation «solidification interlayers» [1-4]. Present study is dedicated to investigation of possibilities for minimizing structural inhomogeneities in $\mathrm{fu}^{-}$ sion zone due to varying composition of deposited metal and value of welding current.

One-layer deposits were made using pilot electrodes of E-10Kh28N14G2 type of $3 \mathrm{~mm}$ diameter over low-carbon steel (St3sp) plates varying welding current in 80-140 A range. Metal-

Table 1. Chemical composition of base and deposited metal, wt.\%

\begin{tabular}{||l|c|c|c|c|c|c||}
\hline \multicolumn{1}{|c|}{ Material } & $\mathrm{Cr}$ & $\mathrm{Ni}$ & $\mathrm{Mn}$ & $\mathrm{Si}$ & $\mathrm{C}$ & $\mathrm{Nb}$ \\
\hline St3sp steel base metal & 0.05 & 0.04 & 0.5 & 0.179 & 0.16 & - \\
\hline Metal deposited by E-08Kh20N9G2B type electrodes & 19.50 & 9.20 & 1.0 & 0.95 & 0.07 & 1.38 \\
\hline
\end{tabular}


Table 2. Effect of welding current on structure and microhardness of fusion zone and deposited metal, produced by E-10Kh28N14G2 electrodes over St3sp steel

\begin{tabular}{||c|c|c|c|c||}
\hline \multirow{2}{*}{$I_{\mathrm{w}}, \mathrm{A}$} & \multicolumn{3}{|c|}{ Microhardness, MPa } & \multirow{2}{*}{ Deposit microstructure } \\
\cline { 2 - 5 } & Fusion zone & Middle part of deposit & Upper part of deposit & \\
\hline $80-90$ & $1595-2580$ & $1688-1760$ & $1875-1940$ & Austenite + ferrite \\
\hline $110-130$ & $1942-3840^{*}$ & $1900-2120$ & $1900-2200$ & Austenite (in fusion zone) + martensite \\
\hline${ }^{*}$ Martensite of transition zone.
\end{tabular}

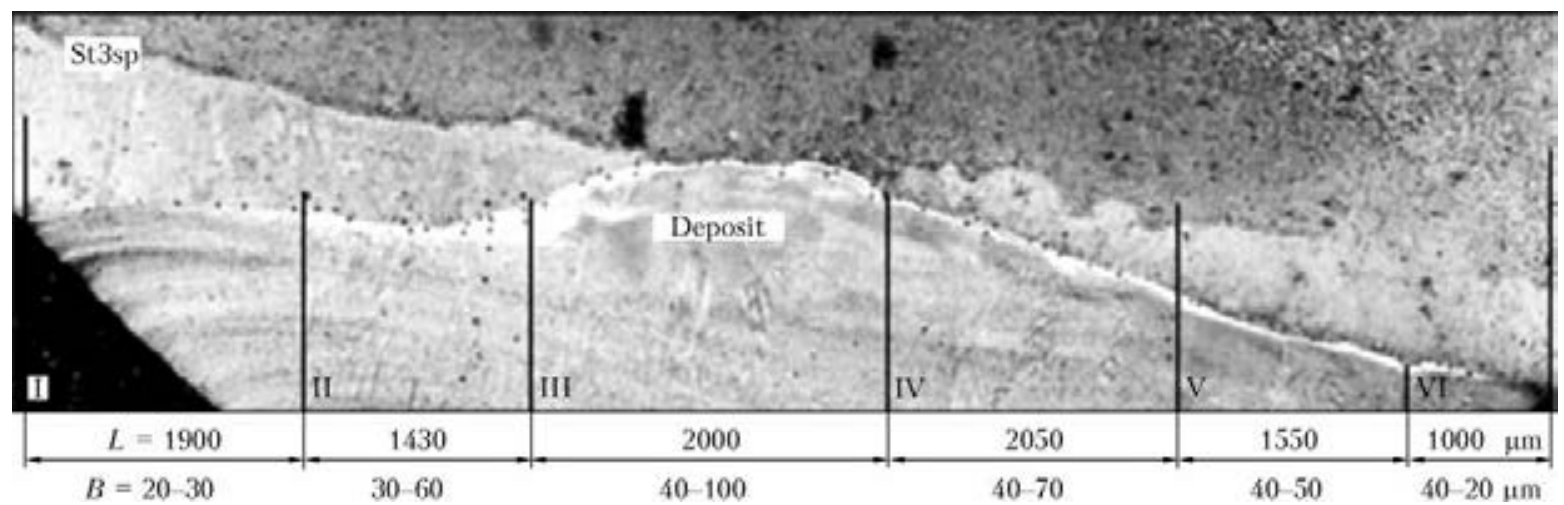

Figure 2. Panoramic sight $(\times 50)$ of transition zone of deposits produced using pilot electrodes of E-10Kh28N14G2 type over St3sp steel at $I_{\mathrm{w}}=80-90$ A: $L-$ length; $B-$ width

lographic examinations were carried out on microsections with evaluation of microhardness of structural constituents. Quantity of magnetic phase in high-alloyed metal was determined using FERRITGEHALT-MESSER 1.053 ferrite meter. The microstructure of deposited metal was examined at «Neophot-32» microscope.

Microhardness (GOSTs 9450-76 and 1071175) was determined at $100 \mathrm{~g}$ loading for evaluation of structural inhomogeneity in the transition zone. Data on chemical composition of metal of transition zone were obtained using energy dispersive X-ray microanalyzer of «Camscan» microscope. Metallographic examinations determined absence of cracks in fusion zone and weld metal deposited by pilot electrodes.

Table 2 shows the changes of microhardness of deposited metal depending on welding current. The transition zone includes an interface between base and highly-alloyed metal of alternating composition (Figure 2). Profile of transition zone was determined using combined chemical and ele-

Table 3. Data of X-ray spectrum analysis of transition zone (3rd area) between steel St3sp and metal deposited by E10Kh28N14G2 type electrodes (wt.\%) at $I_{\mathrm{w}}=80-90 \mathrm{~A}$

\begin{tabular}{|c|c|c|c|c|c||}
\hline No. & $\mathrm{Si}$ & $\mathrm{Cr}$ & $\mathrm{Mn}$ & $\mathrm{Fe}$ & $\mathrm{Ni}$ \\
\hline 1 & 0.16 & 0.67 & 0.36 & 98.81 & - \\
\hline 2 & 0.50 & 15.16 & 1.47 & 75.01 & 7.85 \\
\hline 3 & 0.76 & 18.75 & 2.46 & 67.09 & 10.93 \\
\hline 4 & 0.98 & 26.67 & 2.75 & 53.51 & 16.09 \\
\hline
\end{tabular}

crolythic etching of base low-carbon metal and highly alloyed deposit. It was determined that its width varies in $2-100 \mu \mathrm{m}$ range.

As can be seen from Table 2, microhardness of all areas of transition zone at $I_{\mathrm{w}}=80-90$ A made 1595-2580 MPa, except for one (3rd area) where it reached $3050 \mathrm{MPa}$. In this connection, energy dispersive analyzer was used for determination of content of alloying elements (Tables 3 and 4) in increased hardness area (see Figure 2). Concentration of nickel close to fusion line made 7.85 and that of chromium was 15.16 wt.\%. Microstructure of transition zone of deposited metal in surfacing at $I_{\mathrm{w}} \sim 80-90$ A represents itself austenite $+\sim 3-5 \%$ of ferrite. At that, chromium content nearby the fusion line made 15.214.9 wt. $\%$, that provides for sufficient metal corrosion resistance.

Increase of microhardness up to 1942$3840 \mathrm{MPa}$ is observed from the side of highlyalloyed metal at welding current increase to 100130 A. Metal of transition zone has the following

Table 4. Data of X-ray spectrum analysis of transition zone between steel St3sp and metal deposited by E-10Kh28N14G2 type electrodes (wt.\%) at $I_{\mathrm{w}}=130 \mathrm{~A}$

\begin{tabular}{|c|c|c|c|c|c||}
\hline No. & $\mathrm{Si}$ & $\mathrm{Cr}$ & $\mathrm{Mn}$ & $\mathrm{Fe}$ & $\mathrm{Ni}$ \\
\hline 1 & 0.15 & - & 0.61 & 99.24 & - \\
\hline 2 & 0.45 & 12.44 & 1.51 & 78.74 & 6.86 \\
\hline 3 & 0.64 & 19.69 & 1.71 & 66.14 & 11.81 \\
\hline 4 & 0.44 & 24.09 & 2.76 & 60.15 & 11.19 \\
\hline
\end{tabular}




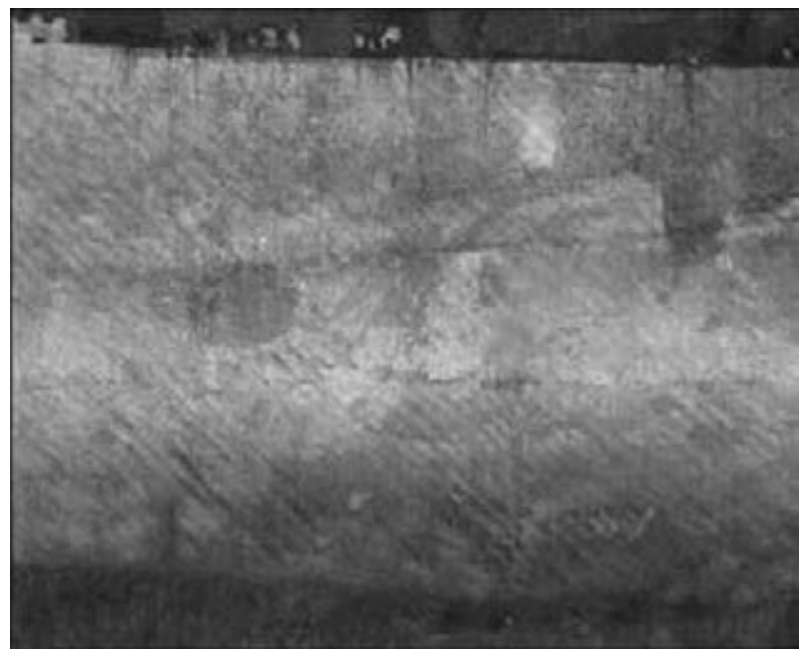

Figure 3. View of part of lining after repair surfacing using ANV-70BG electrodes and polishing of deposited metal

content of alloying elements, wt.\%: $12.44 \mathrm{Cr}$, $6.86 \mathrm{Ni}, 1.51 \mathrm{Mn}$, i.e. phase with martensite constituent is formed in the metal of transition zone together with austenite.

Thus, increase of welding current above $90 \mathrm{~A}$ rises structural and chemical inhomogeneity of metal of transition zone, that can promote for reduction of corrosion resistance and further initiate metal fracture during operation.

Recommendations of optimum modes and methods of welding using new special electrodes of E-10Kh28N14G2 type, providing higher repair quality and long-run serviceability than TsL-11 electrodes, were made as result of carried investigations during repair surfacing of corrosion- and cavitation-resistant layers of metal over operating surface of IC lining of hydropower units.

Testing of specimens of metal deposited using ANV-70BG (Figure 3) and TsL-11 electrodes, carried out at testing benches of laboratory of hydro-gas systems of the National Aviation University, showed that cavitation-wear resistance of metal deposited using ANV-70BG electrodes are 2 times higher than that made by TsL-11 electrodes and hydroabrasive-wear resistance rises by $10 \%$.

TU U 28.7-05416923-099 is registered for ANV-70BG electrodes and technology of their manufacture is mastered at the PWI Pilot Plant of Welding Consumables. The first industrial batches of electrodes were used in repair of IC lining of hydropower units at Kremenchug and Kakhovka HES.

\section{Conclusions}

1. Fracture of metal deposited using TsL-11 electrodes of E-08Kh20N9G2B type over operating surface of IC lining of hydropower units from St3sp steel is caused by formation of martensite phase in the transition zone, promoting corrosion, cracking and delamination of highly-alloyed layer.

2. Risk of formation of martensite in the transition zone and further fracture of deposited layer can be prevented using E-10Kh28N14G2 type electrodes at limitation of electrode diameter and value of welding current.

3. New welding electrodes ANV-70BG of E10Kh28N14G2 type were developed for repair surfacing of corrosion- and cavitation-resistant layer of metal over operating surfaces of lining from St3sp steel of IC of hydropower units. They provide for high corrosion and cavitation resistance of deposited metal.

1. Gotalsky, Yu.N. (1981) Welding of dissimilar steels. Kiev: Tekhnika.

2. Zemzin, V.N. (1966) Welded joints of dissimilar steels. Moscow: Mashinostroenie.

3. Frolov, K.V., Paton, B.E., Belyanin, P.N. (2006) Machine-building: Encyclopedia, Vol. 3, 4. Moscow: Mashinostroenie.

4. Pavlov, I.V., Antonets, D.P., Gotalsky, Yu.N. (1980) To problem of mechanism of transition layer formation in fusion zone of dissimilar steels. Avtomatich. Svarka, 7, 5-7.

Received 25.03.2015 